\title{
Synthesis and Sintering of Zirconia-Erbia Tetragonal Solid Solutions
}

\author{
Stefano MASCHIO, Sergio BRUCKNER and Giuseppe PEZZOTTI* \\ Dipartimento di Scienze e Tecnologie Chimiche, University of Udine, Via Cotonificio 108, 33100 Udine, Italy \\ *Department of Materials, Kyoto Institute of Technology, Matsugasaki, Sakyo-ku, Kyoto-shi 606-8585 \\ ジルコニアーエルビア正方晶固溶体の合成と焼結 \\ Stefano Maschio - Sergio Bruckner - Giuseppe Pezzotti* \\ Dipartimento di Scienze e Tecnologie Chimiche, University of Udine, Via Cotonificio 108, 33100 Udine, Italy \\ *京都工芸㵶維大学工芸学部物質工学科, 606-8585 京都市左京区松ヶ崎御所海道町
}

\begin{abstract}
The preparation of zirconia/erbia tetragonal solid solution was attempted by sintering of powders produced by coprecipitation. Calcined powders were attrition milled and green bodies densified to materials having grain size of a nanometer scale. Fired materials reached high density after firing at any temperatures above $1350^{\circ} \mathrm{C}$ for times of $1 \mathrm{~h}$ or more; they had a tetragonal structure, provided that the erbia content exceeded $1.5 \mathrm{~mol} \%$. Materials containing $1.5 \mathrm{~mol} \%$ erbia consisted of both monoclinic and tetragonal phases, when the firing conditions were selected at the lowest temperature for densification $\left(1 \mathrm{~h}\right.$ at $\left.1350^{\circ} \mathrm{C}\right)$. In all other cases, only the monoclinic structure could be detected. Materials containing $2,2.5$ and $3 \mathrm{~mol} \%$ erbia had tetragonal symmetry. In particular, tetragonal solid solutions contaning 2 mol $\% \mathrm{Er}_{2} \mathrm{O}_{3}$ mantained such structure until their grain size did not exceed $1 \mu \mathrm{m}$, at larger grain sizes they transformed to monoclinic. The tetragonal lattice parameters were measured by X-ray diffraction analysis in all the tetragonal materials and they agreed with those previously reported by other authors. The crystallographic $a / c$ ratio had influence on the grain tranformability: the lower the ratio, the lower the tetragonal/monoclinic transformation ratio.
\end{abstract}

[Received May 6, 1999; Accepted August 23, 1999]

Key-words : Zirconia-erbia solid solution, Tetragonal phase, Synthesis, Sintering

\section{Introduction}

Zirconia is one of the most studied oxide ceramics due to its good mechanical properties, determined by the presence of a metastable tetragonal structure at room temperature. ${ }^{1), 2), 12)}$ Materials made of pure zirconia are incoherent because zirconia is a polymorph material and the hightemperature tetragonal phase, which develops during sintering, spontaneously transforms into monoclinic (with increasing specific volume) on cooling and causes diffuse ruptures in the bulk. As a consequence, in monoclinic monolithic materials, both density and mechanical properties are extremely poor. It is therefore necessary to introduce some stabilizing oxides which have the function of maintaining the tetragonal symmetry also at room temperature, so that the tetragonal-monoclinic transformation does not occur spontaneously on cooling, but after the production, in the presence of an external stress caused by the working conditions.3)-5) For such reasons oxides such as yttria, ${ }^{4), 6)}$ ceria, ${ }^{7), 8)}$ magnesia, ${ }^{9), 10)}$ and many others can be added to pure zirconia to stabilize the tetragonal structure and exploit the transformation toughening mechanism which determines not only high toughness, but also high strength in such materials. ${ }^{11)-13)}$

In addition to the oxides cited above, rare-earth oxides also enable the preparation of tetragonal zirconia polycrystals through rare earth $/ \mathrm{ZrO}_{2}$ tetragonal solid solutions. ${ }^{14)-16)}$ Erbia is one of the less studied rare earth as stabilizing oxide for $\mathrm{ZrO}_{2}$. Few papers document the presence of tetragonal materials in these solid solutions, the region of this binary system rich in zirconia being almost unexplored. In particular, Duran ${ }^{17)}$ studied the system zirconia/erbia and stated that the $\mathrm{ZrO}_{2}-\mathrm{Er}_{2} \mathrm{O}_{3}$ phase diagram shows the presence of monoclinic solutions at low erbia contents, while for higher amounts, cubic and monoclinic phases can be concurrently detected. It was thus suggested that the tetragonal phase could not be obtained at room temperature. However, the preparation process adopted in that work required prolonged thermal treatments which ob- viously determine grain growth, probably over the stabilization limits for such solid solutions. Only recently some authors ${ }^{18), 19)}$ documented the preparation of tetragonal zirconia-erbia solid phase at room temperature, but also in such papers no precise information is available since they are devoted to other physical characteristics such as the analysis of thermoluminescence, ${ }^{18)}$ or the preparation by non-conventional methods. ${ }^{19)}$ In other words, the relation between tetragonality and grain size of the $\mathrm{ZrO}_{2}-\mathrm{Er}_{2} \mathrm{O}_{3}$ solid solution is presently unknown. New investigations are thus required to elucidate the possibilty to produce zirconia/erbia tetragonal solid solutions by a reproducible and relatively inexpensive method, particularly in the zirconia rich region where transformation toughening could give origin to materials having good mechanical properties.

In this work, we report in details the process for preparing tetragonal zirconia-erbia monolithic samples by pressureless sintering (in air) of powders produced by coprecipitation. Erbia content varied in the range 1.5-3.0 mol\%, since higher $\mathrm{Er}_{2} \mathrm{O}_{3}$ amounts determine the presence of non-transformable tetragonal zirconia, and for $7 \mathrm{~mol} \%$ or more erbia content, of the cubic phase.

\section{Experimental procedure}

Preparation of 1.5, 2.0, 2.5 and $3.0 \mathrm{~mol} \% \mathrm{ZrO}_{2} / \mathrm{Er}_{2} \mathrm{O}_{3}$ solid-solution powders was performed by coprecipitation. Mixtures of $\mathrm{ZrOCl}_{2} \cdot 8 \mathrm{H}_{2} \mathrm{O}$ (99.0\% Aldrich Chem.) and $\mathrm{Er}\left(\mathrm{NO}_{3}\right)_{3} \cdot 5 \mathrm{H}_{2} \mathrm{O}$ (99.9\% Aldrich Chem.) were dissolved into distilled water to give a $0.5 \mathrm{~mol} \%$ solution. Zirconium oxychloride octahydrate is a relatively cheap precursor to produce zirconium oxide, while erbium nitrate hydrate was preferred to chloride because nitrogen compounds can be eliminated more easily than chlorides so that final materials are cleaner.

The solution was poured dropwise while stirring into concentrated ammonia (28 mass\%) at room temperature. After coprecipitation the product was maintained under stirring for $2 \mathrm{~h}$ to allow for complete reaction of the com- 
ponents. The precipitated product was then washed several times with deionized water and then with a successive acetone-toluene-acetone washing procedure. ${ }^{20)}$ The powders were heated at $80^{\circ} \mathrm{C}$ in an oven and sieved through a $63 \mu \mathrm{m}$ sieve. Their simultaneous thermal analysis (STA) diagram was obtained on a Netzsch STA equipment at a heating rate of $10^{\circ} \mathrm{C} / \mathrm{min}$ up to a temperature of $1250^{\circ} \mathrm{C}$; on the ground of this information, the calcination cycle of the powders was selected as $1 \mathrm{~h}$ at $650^{\circ} \mathrm{C}$.

Powders were first attrition milled for $6 \mathrm{~h}$ in a plastic container with zirconia/yttria $(3 \mathrm{~mol} \%)$ spheres at 300 cycle/min using isopropanol as dispersing medium. Attrition milling causes wear of the milling balls which determines contamination of zirconia/erbia powders by yttria. In order to minimize the contamination $30 \mathrm{~g}$ of powders were processed each time and consequently the amount of yttria was calculated below $1 \mathrm{~mol} \%$; this value can be considered neglible since the starting zirconia precursor have a similar purity.

After drying and sieving, powders were uniaxially pressed at $30 \mathrm{MPa}$ to give cylinders ( $8 \mathrm{~mm} \mathrm{D}, 25 \mathrm{~mm} \mathrm{~h})$, which were then isostatically pressed at $300 \mathrm{MPa}$. Sintering was performed in air into within a $\mathrm{MoSi}_{2}$ heated muffle at various times and temperatures. The density of the sintered bodies was evaluated by the water diplacement technique.

$\mathrm{X}$-ray diffraction data were recorded on an XRG 300 Inel powder diffractometer equipped with CPS 120 detector. Monochromated $\mathrm{Co} \mathrm{K} \alpha_{1}$ was ontained by setting $35 \mathrm{kV}$ and $20 \mathrm{~mA}$ operating conditions. Calibration of $2 \theta$ scale was carried out with the aid of a corundum sample. The position of diffracted peaks was determined with the aid of the software package WINFIT. ${ }^{21}$ Refinement of unit cell parameters was performed with the aid of a home-made computer program. Refined values of cell parameters and an extimate of the zero-shift on the $2 \theta$ scale were obtained. Two samples were analized which contained 2 and $3 \mathrm{~mol} \%$ $\mathrm{Er}_{2} \mathrm{O}_{3}$ by recording their powder diffraction data, locating 18 peaks for each sample and running the last-square routine. The tetragonal/monoclinic ratios both on powders and on sintered specimens were accessed by X-ray intensity measurements according to the Garvie and Nicholson equation. ${ }^{22)}$ The microstructures were examined by an Assing Stereoscan scanning electron microscope (SEM) and the average grain size was determined by the lineal intercept method.

\section{Results and discussion}

STA analysis of the 4 powders containing different amounts of erbia did not show any appreciable difference. Heating and phase crystallization occurred at low temperature concurrently with a weigth loss which ended at $550^{\circ} \mathrm{C}$ for all compositions. Consequently, coprecipitated and dried powders were calcined at $650^{\circ} \mathrm{C}$ in order to ensure no organic compounds to remain entrapped into the powders particles. In this context, selecting a temperature $100^{\circ} \mathrm{C}$ higher than that indicated by STA tests was considered to be a sufficient condition to remove all evaporating products during the calcination treatment. All powders had a complete tetragonal symmetry after calcination, but attrition milling partly transformed this phase into monoclinic (Fig. 1). In particular, powders containing 1.5 mol\% $\mathrm{Er}_{2} \mathrm{O}_{3}$ completely transformed. These data show, as expected, that the percentage of transformable tetragonal phase decreases with increasing erbia content.

Sintering at $1350^{\circ} \mathrm{C}$ for $1 \mathrm{~h}$ produced samples of low density $\left(<95 \%\right.$ theoretical), those containing $1.5 \mathrm{~mol}^{\circ} \mathrm{Er}_{2} \mathrm{O}_{3}$ being mainly monoclinic (80\%) and all the others mainly tetragonal. We suppose that the former have low density also because the monoclinic phase determines many

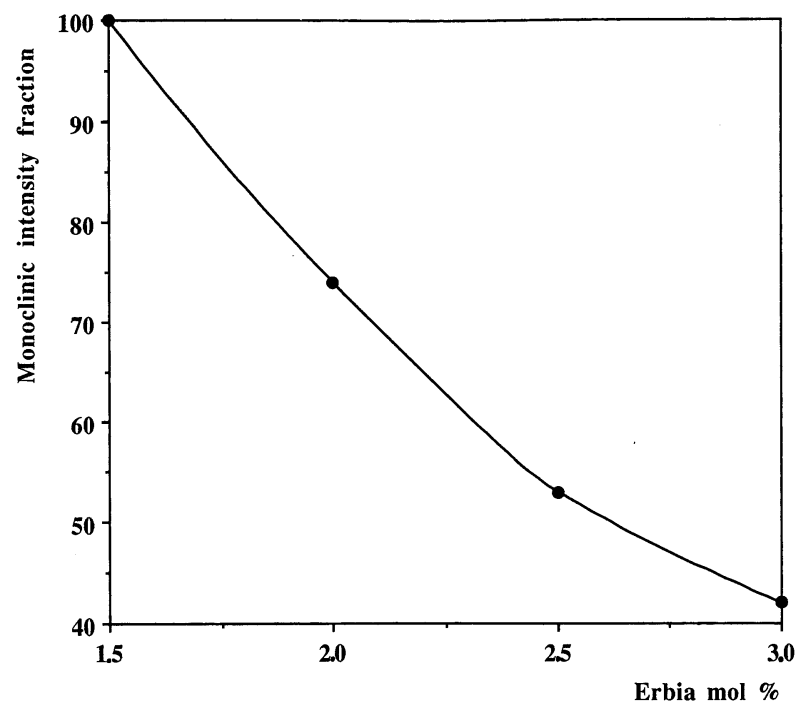

Fig. 1. Monoclinic intensity fraction vs. erbia content after attrition milling of calcined powders.

microcracks in the bulk. Sintering at $1350^{\circ} \mathrm{C}$ for longer times did not produce any significant enhancement of density, nor an increase in transformation of the tetragonal phase into monoclinic in specimens containing higher amounts of erbia. Test performed at $1450^{\circ} \mathrm{C}$ enabled the preparation of dense materials ( $>97 \%$ theoretical) for all compositions, except samples containing $1.5 \mathrm{~mol} \% \mathrm{Er}_{2} \mathrm{O}_{3}$ which are fully monoclinic. Sintering time seems to be not influent (as samples have high density) after $1 \mathrm{~h}$, and density values do not increase for more severe thermal treatments. In fact, density reaches the maximum (98\% of theoretical) for materials containing 2.0, 2.5 and $3.0 \mathrm{~mol} \% \mathrm{Er}_{2} \mathrm{O}_{3}$ after $2 \mathrm{~h}$ and then remains constant for longer firing times. The results of the sintering experiments are summarized in Figs. 2 and 3 . Samples containing 2.0 and $3.0 \mathrm{~mol} \% \mathrm{Er}_{2} \mathrm{O}_{3}$ and fired for $2 \mathrm{~h}$ were characterized by X-ray analysis in order to determine their cell parameters. Refined cell parameters are reported in Table 1 . The refined values of the cell parameters and the $a / c$ ratio show substantial agreement with data reported by Khor and Yang. ${ }^{19)}$ Differences

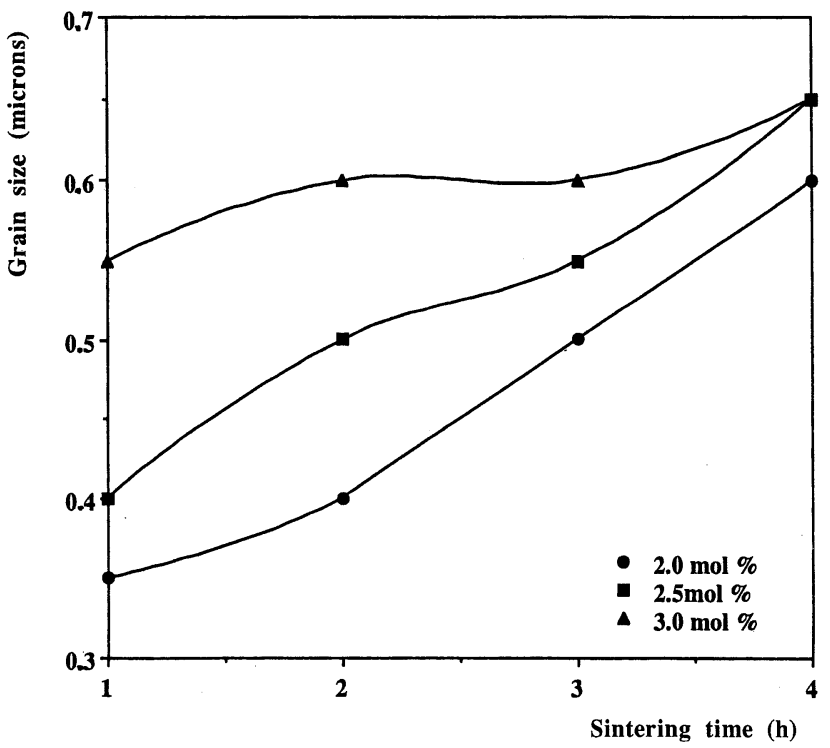

Fig. 2. Average grain size as a function of sintering time of samples fired at $1450^{\circ} \mathrm{C}$. 


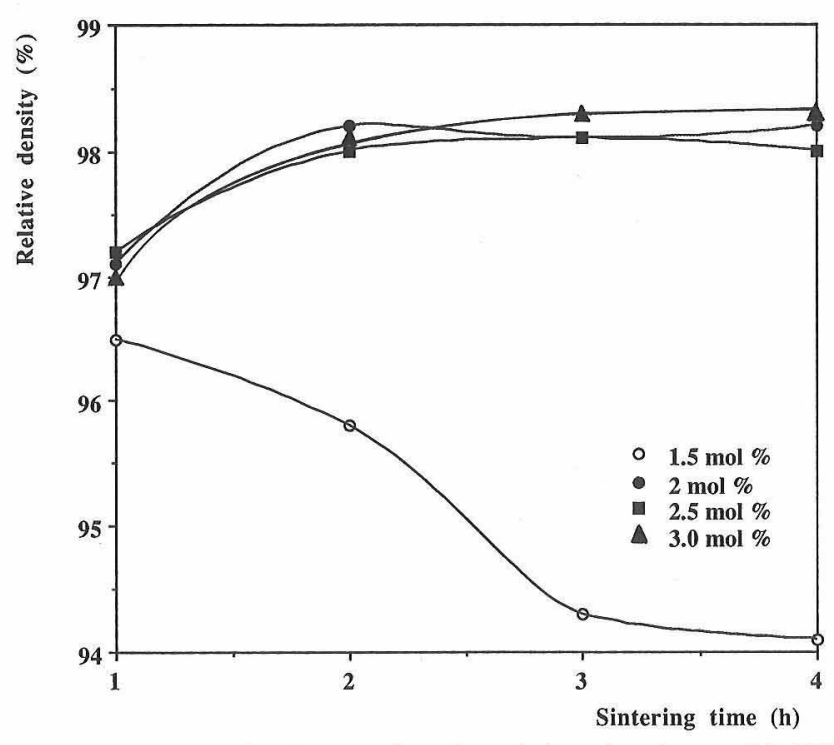

Fig. 3. Relative density as a function of sintering time at $1450^{\circ} \mathrm{C}$.

Table 1. Cell Parameters of Samples Containing 2.0 and 3.0 $\mathrm{mol} \% \mathrm{Er}_{2} \mathrm{O}_{3}$ Fired $2 \mathrm{~h}$ at $1450^{\circ} \mathrm{C}$; Standard Deviations are in Parentheses

\begin{tabular}{|l|l|l|}
\hline & $2.0 \mathrm{~mol} \% \mathrm{Er}_{2} \mathrm{O}_{3}$ & $3.0 \mathrm{~mol} \% \mathrm{Er}_{2} \mathrm{O}_{3}$ \\
\hline $\mathrm{a}=\mathrm{b}(\mathrm{nm})$ & $0.5088(0.0002)$ & $0.5089(0.0003)$ \\
\hline $\mathrm{c}(\mathrm{nm})$ & $0.5175(0.0003)$ & $0.5170(0.0003)$ \\
\hline
\end{tabular}

between the two samples are of the order of standard deviations.

Samples sintered at $1550^{\circ} \mathrm{C}$ did not show appreciable differences as compared with those sintered at $1450^{\circ} \mathrm{C}$ except for samples containing $2.0 \mathrm{~mol} \%$ where the presence of the monoclinic phase was detected after firing for $4 \mathrm{~h}$.

Figures 4(a), (b) and (c) show the microstructures of as fired samples contaning $2.0,2,5$ and $3.0 \mathrm{~mol} \%$ erbia, respectively, fired $2 \mathrm{~h}$ at $1450^{\circ} \mathrm{C}$. It can be seen that the grains are extremely fine, their average size being $0.4,0.5$ and $0.6 \mu \mathrm{m}$, respectively. We emphasize that all the three solid solutions have grain size below $1 \mu \mathrm{m}$ and their dimensions slowly increase with increasing the erbia content. Such microstructures are in agreement with the results of other researchers who demostrated that tetragonal zirconia materials have commonly grain sizes $\leq 1 \mu \mathrm{m} .{ }^{3), 5), 12)}$ It seems that the addition of $\mathrm{M}_{2} \mathrm{O}_{3}$ type oxides to zirconia retards the grains growth (as in the case of yttria) more than the addition of $\mathrm{MO}$ or $\mathrm{MO}_{2}$ types oxides. Moreover, being the ionic radius of erbium larger than that of many others elements, bulk diffusion, during the sintering process is extremely slow. As a consequence, materials contaning $\mathrm{Er}_{2} \mathrm{O}_{3}$ tetragonal zirconia show fine microstructures even if the thermal treatments are performed at relatively high temperatures.

Figure 5 shows a SEM micrograph of a sample contaning $2 \mathrm{~mol} \%$ erbia after sintering $4 \mathrm{~h}$ at $1550^{\circ} \mathrm{C}$. In such sample, the presence of the monoclinc phase $(\sim 10 \%)$ was detected together with the tetragonal phase. This photo documents the presence of some microcracks around some grains having dimensions of about $1 \mu \mathrm{m}$. We argue that $1 \mu \mathrm{m}$ is an upper limit for the stabilization of the tetragonal phase in materials contaning $2.0 \mathrm{~mol} \%$ erbia, being tetragonal those having lower grain size and monoclinic those having a higher one. In this work, it was not possible to determine the spontaneous transformation limit for materials containing higher mol\% erbia since the most severe thermal treat-

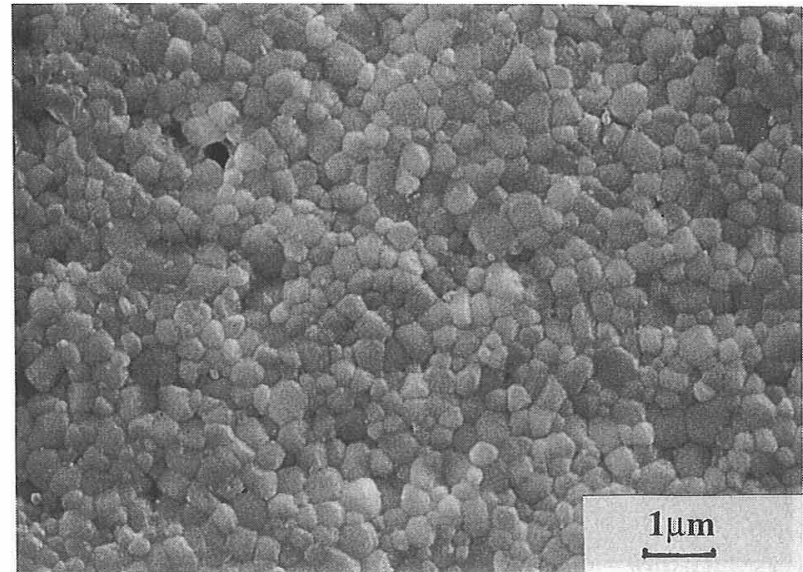

(a)

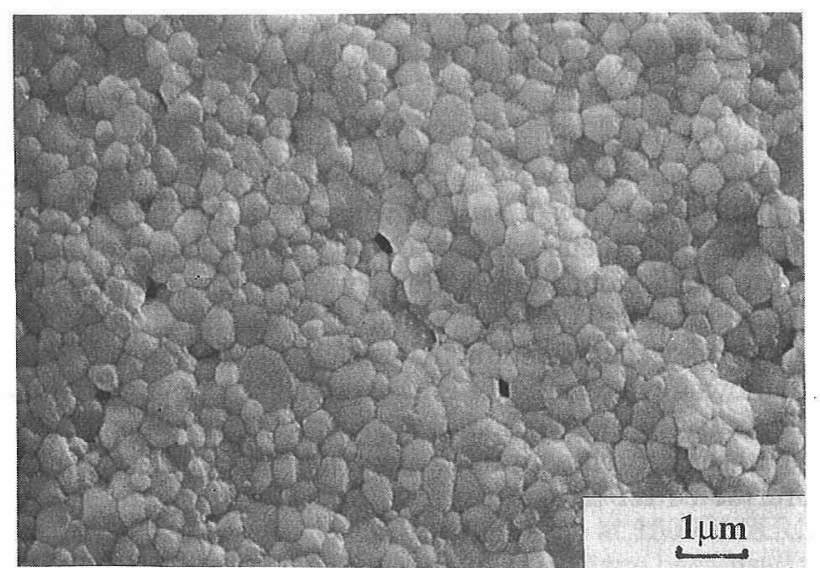

(b)

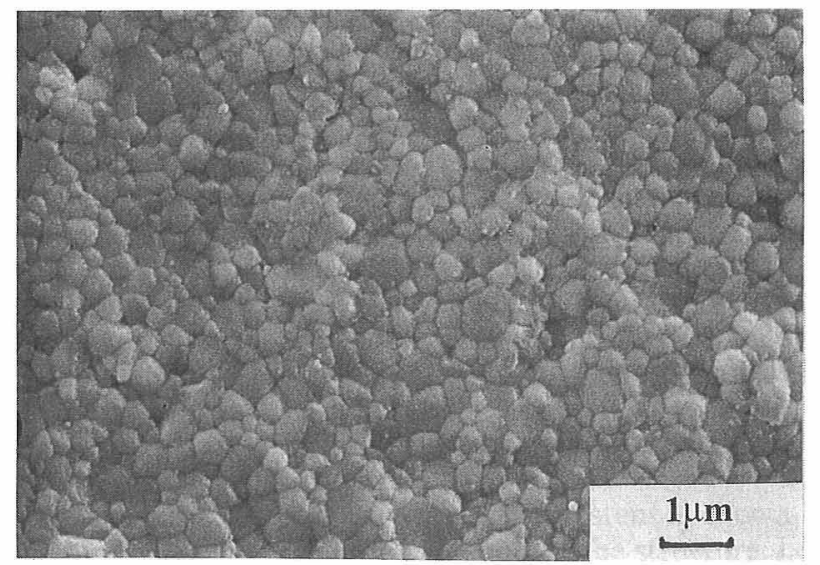

(c)

Fig. 4. SEM images of the as-fired $\left(1450^{\circ} \mathrm{C}, 2 \mathrm{~h}\right)$ surfaces of the three materials containing:

(a) $2.0 \mathrm{~mol} \% \mathrm{Er}_{2} \mathrm{O}_{3}$, (b) $2.5 \mathrm{~mol} \% \mathrm{Er}_{2} \mathrm{O}_{3}$, (c) $3.0 \mathrm{~mol} \% \mathrm{Er}_{2} \mathrm{O}_{3}$.

ment made $\left(4 \mathrm{~h}, 1550^{\circ} \mathrm{C}\right)$ gave samples contaning only tetragonal grains. Specimens contaning 2.5 and $3.0 \mathrm{~mol} \%$ $\mathrm{Er}_{2} \mathrm{O}_{3}$ thus maintained the tetragonal symmetry also when their grain size exceeds $1.5 \mu \mathrm{m}$.

\section{Conclusions}

Coprecipitation, followed by attrition milling of calcined powders, enabled the synthesis of zirconia/erbia tetragonal solid solutions at room temperature. X-ray analysis demonstrated that monolithic materials containing 1.5 mol\% erbia transformed to monoclinic on cooling after sintering while those containing $2.0,2.5$ and $3.0 \mathrm{~mol} \%$ 


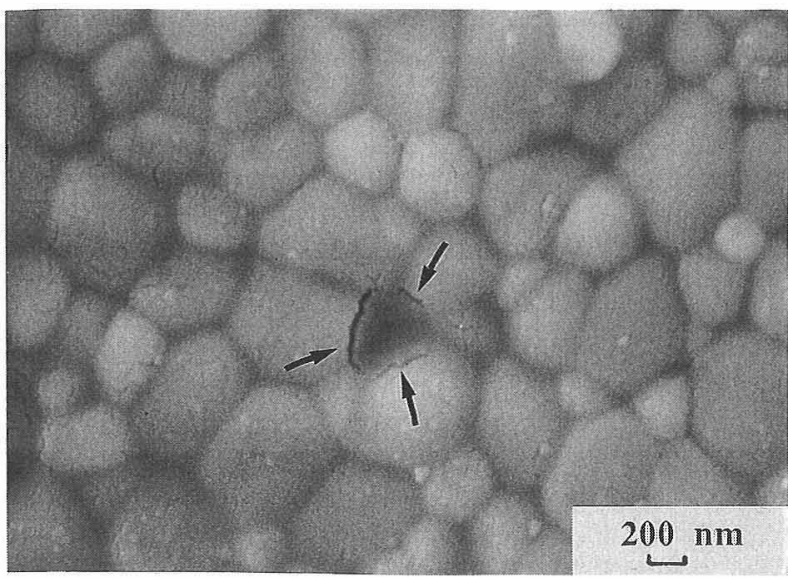

Fig. 5. SEM micrograph of a sample containing $2.0 \mathrm{~mol} \% \mathrm{Er}_{2} \mathrm{O}_{3}$ fired $4 \mathrm{~h}$ at 1550 . Arrows indicate some microcracks around grains having dimensions of about $1 \mu \mathrm{m}$.

remained fully tetragonal. The microstructure of these samples appears to be extremely fine and their average grain size is below $1 \mu \mathrm{m}$ also when the sintering process is severe. Specimens containing $2.0 \mathrm{~mol} \%$ erbia showed the presence of monoclinic symmetry when samples were fired for $4 \mathrm{~h}$ at $1550^{\circ} \mathrm{C}$. In this material, a limited fraction of grains exceeded the dimension of $1 \mu \mathrm{m}$. No critical dimension was determined in materials containing higher amounts of erbia as the full tetragonal symmentry was present at room temperature even when sintering process was protracted for long periods at $1550^{\circ} \mathrm{C}$.

\section{References}

1) K. Tsukuma, Y. Kubota and T. Tsukidate, "Advances in Ceramics, Vol. 12, Science and Technology of Zirconia II," Ed. by N. Claussen, M. Rühle and A. H. Heuer, Am. Ceram.
Soc., Columbus, OH (1984) pp. 382-90.

2) M. Matsui, M. Soma and I. Oda, "Advances in Ceramics, Vol. 12, Science and Technology of Zirconia II," Ed. by N. Claussen, M. Rühle and A. H. Heuer, Am. Ceram. Soc., Columbus, $\mathrm{OH}$ (1984) pp. 371-81.

3) F. F. Lange, J. Am. Ceram. Soc., 69, 240-42 (1986).

4) M. Yoshimura, Am. Cearm. Soc. Bull., 67, 1950-55 (1988).

5) F. F. Lange, D. B. Marshall and J. R. Porter, "Ultrastructure Processing of Advanced Ceramics," Ed. by J. D. Mackenzie and D. R. Ulrich, John Wiley and Sons, N. Y. (1988) pp. 51932.

6) H. Suto, T. Sakuma and N. Yoshikawa, Trans, of the Jap. Inst. of Metals, 38, 623-30 (1987).

7) R. C. Garvie, R. H. Hannink and R. T. Pascoe, Nature (London), 258(5537), 703-04 (1975).

8) T. Y. Tseng, C. C. Lin and J. T. Liau, J. Mater. Sci., 22, 96572 (1987)

9) E. Tani, M. Yoshimura and S. Sōmiya, J. Am. Ceram. Soc., 66, 506-10 (1983)

10) S. Meriani and G. Spinolo, Powd. Diffr., 2, 225-28 (1987).

11) T. Masaki and K. Shinjo, Ceram. Int., 13, 109-12 (1987).

12) K. Tsukuma and M. Shimada, J. Mater. Sci., 20, 1178-84 (1985).

13） L. R. F. Rose and M. V. Swain, J. Am. Ceram. Soc., 69, 20307 (1986)

14) G. Pretorius, J. Mater. Sci., 30, 720-23 (1995).

15) E. R. Andrievskaya and L. M. Lopato, J. Mater. Sci., 30 , 2591-96 (1995).

16) T. Kiguki, A. Saiki, K. Shinozaki, K. Terayama and N. Mizutani, J. Ceram. Soc. Japan, 105, 775-78 (1997).

17) P. Duran, J. Am. Ceram. Soc., 60, 510-13 (1977).

18) W. C. Hsieh and C. S. Su, J. Phys. D: Appl. Phys., 27, 176368 (1994).

19) K. A. Khor and J. Yang, Mater. Lett., 31, 23-27 (1997).

20) Chiu Bi-Shiu, W. Y. Hsu and J. G. Duh, J. Mater. Sci. Lett., 5, 931-34 (1986).

21) S. Krumm, Mater. Sci. Forum, Vols. 228-231, 183-88 (1996).

22) R. C. Garvie and P. S. Nicholson, J. Am. Ceram. Soc., 55, 303-35 (1972). 